\title{
Bromatological Analysis and Antioxidant Capacity of Hibiscus sabdariffa L. in Cuba
}

\author{
Francis Brown1, José González 2*, Enrique C. Cejas', Max Monan ${ }^{3}$, Iván S. Sayago ${ }^{4}$ \\ ${ }^{1}$ Dirección de Ciencia Tecnología e Innovación, Universidad de Ciencias Pedagógicas “Enrique Jose Varona”, La Habana, Cuba \\ ${ }^{2}$ Facultad de Educación en Ciencias Técnicas, Universidad de Ciencias Pedagógicas "Enrique Jose Varona”, La Habana, Cuba \\ ${ }^{3}$ ARVARNAM, Martinica, France \\ ${ }^{4}$ Instituto de Investigaciones Fundamentales en Agricultura Tropical “Alejandro de Humboldt” (INIFAT), La Habana, Cuba \\ Email: *jgyaque@ucpejv.edu.cu
}

How to cite this paper: Brown, F., González, J., Cejas, E.C., Monan, M. and Sayago, I.S. (2020) Bromatological Analysis and Antioxidant Capacity of Hibiscus sabdariffa L. in Cuba. Open Access Library Journal, 7: e5920.

https://doi.org/10.4236/oalib.1105920

Received: November 14, 2019

Accepted: January 17, 2020

Published: January 20, 2020

Copyright $\odot 2020$ by author(s) and Open Access Library Inc.

This work is licensed under the Creative Commons Attribution International License (CC BY 4.0).

http://creativecommons.org/licenses/by/4.0/

\begin{abstract}
Towards authentication and quality assurance of medicinal plants, calyces of Hibiscus sabdariffa L. recollected from the Experimental Station of Medicinal Plants "Dr Juan Tomas Roig" between January and April 2016 were analyzed to determine its bromatological properties (moisture content; dry matter; fat; protein; total ash; mineral contents) and its antioxidant capacity using FRAP assay $\left(24.4 \mu \mathrm{mol} \mathrm{Fe} \mathrm{F}^{2+} / 100 \mathrm{~g}\right.$ of fresh mass). Total ash $(6.90 \%)$ and moisture content $(10.05 \%)$ tested are within the World Health Organization (WHO) standards for crude drug from medicinal plants. Mineral contents expressed in $\mathrm{mg} / 100 \mathrm{~g}$ (Fe: 41.17; Ca: 1522.50; K: 2557.50) are higher than foods that are excellent sources of those nutritional elements. Magnesium (242.50) and Sodium (152.25) contents are satisfactory taking into account the importance of these macrominerals for human body.
\end{abstract}

\section{Subject Areas}

Biochemistry, Biodiversity, Cell Biology, Plant Science

\section{Keywords}

Hibiscus sabdariffa, Calyces, Bromatological Analysis, Antioxidant Capacity, Mineral Content

\section{Introduction}

The spices Hibiscus sabdariffa comprises a large number of cultivated types which, on the basis of their growth habit or end use, are classified broadly under two varieties, $H$. sabdariffa var. sabdariffa and $H$. sabdariffa var. altissima Wester. Former is generally bushy and pigmented and cultivated for edible calyces; 
the latter includes tall-growing, unbranched types bearing inedible calyces and mainly cultivated for stem fibre, roselle [1].

The calyces are rich in acid and pectin. Analysis of calyces has shown the presence of crude protein and minerals as iron, phosphorous, calcium, manganese, aluminum, magnesium, sodium and potassium. Mucilage, calcium citrate, ascorbic acid, gossypetin and hibiscin chloride are also present in calyces [1].

H. sabdariffa is a hardy herbaceous shrub, grows well in most soils that are well drained. The flowers are hermaphrodite and are pollinated by insects. It requires a monthly rainfall ranging from 130 to $260 \mathrm{~mm}$ in the first 3 to 4 months of growth. Rain and high humidity during harvest and drying can downgrade the quality of calyces and reduce the yield [2] [3].

Roselle is usually propagated by seed but grows readily from cuttings. The latter method results in shorter plants preferred in India for interplanting with tree crops but the yield of calyces relatively low. The plants may be cut off 6 weeks after transplanting, leaving only $7.5-10 \mathrm{~cm}$ of stem in the field. A second cutting is made 4 weeks later and a third after another 4 weeks. Then plants are thinned out and the remaining plants left to grow and develop fruit as a second product [4].

The physicochemical analysis of the fresh calyces showed that the moisture content (9.2\%) was inside the WHO parameters; total ash (6.90\%) was higher than the accepted value to this physicochemical characteristic permitted for medicinal plants (less than $5 \%$ ), while for the fresh leaves was $86.2 \%$ and $1 \%$, respectively according to the previous data reported by [5].

Taking into account the International Studies, in Cuba, this medicinal plant has reached an important place due to its pharmacological potentialities and their use of nutritional food. Popular known as Serení, the plant is used as diuretic, antiparasitic, cicatrizing, hypotensive, and laxative [6].

There is not any evidence in scientific literature of studies related with this medicinal plant; for that purpose, the aim of this research work was to evaluate the bromatological and antioxidant activity of a cultivar from $H$. sabdariffa known necessary aspects in the development of its monograph and to support its medicinal use.

\section{Materials and Methods}

\subsection{Sample Collection and Processing}

Fresh calyces of the plant (Gerzy cultivar) were collected in experimental areas of Experimental Station of Medicinal Plants Dr. "Juan Tomas Roig", between April and May 2016. Calyces firstly were dried at shadow during a period of 10 15 days and after in an oven at $37^{\circ} \mathrm{C}$ for 12 hours and powdered by hand using a meet mill. Figure 1 shows some morphological details of the cultivar used in this research.

\subsection{Extracts Preparation}

The extracts were prepared with the ground material $(60 \mathrm{~g})$ without screen 


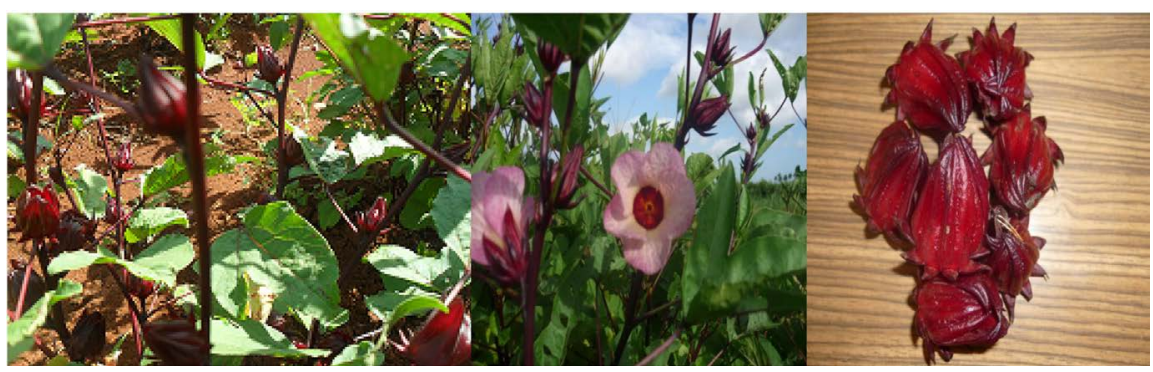

Figure 1. Morphological details of Gerzy cultivar from H. sabdariffa L. in Cuba.

extracted in a Soxhlet apparatus with $675 \mathrm{~mL}$ of $n$-hexane during 20 hours. The extracts were concentrated and evaporated under vacuum to $200 \mathrm{~mL}$ at $120 \mathrm{rpm}$, a temperature of $70^{\circ} \mathrm{C}$ and 500 mbar according to [7]. All reagents used were of analytical grade (Merck). All solvents were degassed prior to use in an ultrasonic bath without filtration.

\subsection{Bromatological Analysis}

Bromatological analyses were realized in Chemical and Bromatological Laboratories of INIFAT and IIIA in Havana, Cuba, determining the following parameters: dry matter, fat, moisture, protein, ash, calcium and phosphorous under the standard procedures mentioned in the general rule of WHO and the Cuban NRSP 312 [8] [9].

\subsection{Mineral Content}

The mineral content was realized using the Atomic Absorption Equipment from Research Institute of Food Industry (IIIA) in Havana, Cuba, under the procedures mentioned in AOAC, 2016 [10].

\subsection{Antioxidant Capacity}

The Ferric Reducing Antioxidant Power (FRAP) assay was measured as described previously by [11], which determine the ability of the sample to reduce iron ferric $\left(\mathrm{Fe}^{3+}\right)$ to ferrous $\left(\mathrm{Fe}^{2+}\right)$. The determinations were carried out in a spectrophotometer Rayleigh UV-1601 (China) at $593 \mathrm{~nm}$. The extract was tested at 20,30 and $40 \mu \mathrm{g} / \mathrm{mL}$ concentrations. The results were expressed as $\mu \mathrm{mol}$ of $\mathrm{Fe}^{2+} / 100 \mathrm{~g}$ of sample.

\subsection{Statistical Analysis}

All analyses were conducted in triplicate $(\mathrm{n}=3)$, and an ANOVA test (using SPSS statistical software) was used to compare the mean values of each treatment. Significant differences between the means of parameters were determined by using the Duncan test $(\mathrm{p}<0.05)$.

\section{Results and Discussion}

\section{1) Bromatological analysis}


Table 1 summarized the results reached in bromatological analysis realized to the $H$. sabdariffa cultivars used in the experiments. Moisture content $(10.06 \%)$ was inside the limited index $(8 \%-14 \%)$. Total ash $(6.90 \%)$ is higher to the standard allowed by WHO (3\% - 5\%) for medicinal plants, implying that the crude plant has low inorganic components, although this value is lower than the standard of Pharmacopoeia of the People's Republic of China [12].

In the other hand, this spice showed a very good value of fat content $(5.02 \mathrm{~g}$ ) being this value higher than the same parameter that was $2.61 \mathrm{~g}$. Dry matter was $56.40 \mathrm{~g}$, while Protein content was $94.10 \mathrm{~g}$, being this result very significant comparing with the result reached by the last mentioned authors (1.145 g) because of the role of this chemical components in different structural, defensive, regulation and transport functions in human body [13].

Minerals play an important role in the nutritional state of population in the world. For their implication in keeping a healthy mind and body, their levels must be adequate. Phosphorous determination reached a value of $4.10 \mathrm{~g}$ higher than the previous evaluation where this element got the amount of $273.3 \mathrm{mg}$. Iron $(41.17 \mathrm{mg}$ ) and Calcium (1522.50 mg) were much higher than the same assays done to these two important chemical elements previously reported. Their values were $8.98 \mathrm{mg}$ and $12.63 \mathrm{mg}$, respectively [14].

\section{2) Mineral content}

Table 2 summarized the preliminary evaluation of the content of those mineral elements assayed in this investigation. Calyces of Roselle have a significant mineral content. Iron, Calcium and Potassium content was high, showing a remarkable amount level above the Recommend Dietary Allowances (RDA) for women and men per day. Only Zinc, Magnesium and Sodium content was found under the recommended doses for adults per day.

Table 1. Bromatological analysis of H. sabdariffa L. in Cuba.

\begin{tabular}{cc}
\hline Parameters & Results \\
\hline Moisture & $10.06 \%$ \\
Dry matter & $56.40 \mathrm{~g}$ \\
Fat & $5.02 \mathrm{~g}$ \\
Protein & $94.10 \mathrm{~g}$ \\
Ash & $6.90 \%$ \\
Phosphorous & $4.10 \mathrm{~g}$ \\
\hline
\end{tabular}

Table 2. Mineral composition (mg/100g) of H. sabdariffa in Cuba.

\begin{tabular}{|c|c|c|c|c|c|c|c|}
\hline Sample & $\mathrm{Fe}$ & $\mathrm{Zn}$ & $\mathrm{Cu}$ & $\mathrm{Ca}$ & $\mathrm{Mg}$ & $\mathrm{K}$ & $\mathrm{Na}$ \\
\hline H. sabdariffa & 41.17 & 2.80 & 1.14 & 1522.50 & 242.50 & 2557.50 & 152.25 \\
\hline $\begin{array}{c}\text { RDA } \\
\text { (mg/day) } \\
\text { In adults }\end{array}$ & $\begin{array}{c}20 \\
\text { (women) } \\
14 \text { (men) }\end{array}$ & $\begin{array}{c}10 \\
\text { (women) } \\
14 \text { (men) }\end{array}$ & 0.9 & 800 & $\begin{array}{c}300 \\
\text { (women) } \\
350 \\
\text { (men) }\end{array}$ & 2000 & 500 \\
\hline
\end{tabular}


Mineral composition depending of the relative equilibrium moisture contents in different environments and lengths of time of sun drying. The variation of ash and mineral elements contents could be a result of factors such as soil $\mathrm{pH}$, soil nutrients, and/or level of fertilizer applied. With regard to human nutritional aspects, Roselle calyces have a significant mineral content.

\section{3) Antioxidant capacity}

The FRAP method also showed a higher antioxidant capacity for the experimental extract of $H$. sabdariffa in Cuba. The resulting value was $24.4 \mu \mathrm{mol}$ $\mathrm{Fe}^{2+} / 100 \mathrm{~g}$ of sample demonstrating that in our country the cultivated spice has similar antioxidant capacity behaviour like the same reported assays found by [15] [16] [17]. Our result now was higher than the same assay found in extracts of Guettarda calyptrate A. Rich. by our research team in 2018 using an extract with a concentration of $20 \mu \mathrm{g} / \mathrm{mL}(21.24 \pm 1.75 \mu \mathrm{M}$ equivalents of ascorbic acid) according to [18].

\section{Conclusion}

From the study, important diagnostic characters that might be useful in determining authenticity and identifying adulteration of the crude drug are observed. Physicochemical parameters like ash values, and moisture content are all indicators of quality herbal medicine, which help to determinate the physiological and non-physiological ash, possibility of microbial growth or contamination and presence of impurities respectively. Natural antioxidants play an important role in front of oxidative stress, possessing antimutagenic, anticarcinogenic, and antiinflammatory and neuroprotective effects. It seems to be that antioxidant capacities of extracts from Roselle are depending on extract concentration and the type of solvent used for their elaboration. According to those results, the presence of phenolic compounds and particularly anthocyanins are recognized by its antioxidant activity. The last evidence suggests that at least part of the antioxidant effect founded for the extracts of $H$. sabdariffa could be associated with those components. Mineral content of the calyces joining with the anthocyanins present in this component part of the flowers may be contributed to sustain and improve the attributed pharmacological properties of this edible plant. It provides reference basis for formulating quality standard of $H$. sabdariffa L. authenticity of medicinal herbs and resource utilization.

\section{Acknowledgements}

Authors confirm that this research did not receive any specific grant from funding agencies in the public, commercial, or not-for-profit sectors.

\section{Conflicts of Interest}

The authors declare no conflict of interest.

\section{References}

[1] Gautam, R.D. (2004) Sorrel-A Lesser-Known Source of Medicinal Soft Drink and 
Food in India. Natural Product Radiance, 3, 338-342.

[2] Duke, J.A. (1983) Handbook of Energy Crops.

http://www.hort.purdue.edu/newcrop

[3] McCaleb, S., Evelyn, L. and Krista, M. (2000) The Encyclopedia of Popular Herbs, Prima Lifestyles.

[4] Julia, F. (1987) Roselle. In: Fruits of Warm Climates, Miami, FL, 281-286.

http://www.hort.purdue.edu/newcrop/morton/roselle.html

[5] Mahadevan, N., Shivali and Kamboj, P. (2009) Hibiscus sabdariffa Linn-An overview. Natural Product Radiance, 8, 77-83.

[6] Roig, J.T. (2014) Plantas medicinales, aromáticas y venenosas de Cuba. Editora Ciencia y Técnica. Instituto del Libro, La Habana, 949 p.

[7] González, J., Pérez, J., Cuéllar, A., Gómez, E., Gutiérrez, Y.I., Scull, R., Salgado, D. and Monan, M. (2019) Pharmacognostic, Physicochemical and Phytochemical Analysis of Fruits of Talipariti elatum (Sw.) in Cuba. Open Access Library Journal, 6, e5300. https://doi.org/10.4236/oalib.1105300

[8] Lou, Z.-C. (1980) General Control Methods for Vegetable Drugs. Comparative Study of Methods Included in Thirteen Pharmacopoeias: A Proposal on Their Internacional Unification. WHO/PHARM/80.502, 8-39.

[9] NRSP 309 (1992) Norma Ramal. Medicamentos de origen vegetal. Droga cruda. Métodos de ensayo, 16-29.

[10] AOAC (2016) Official Methods of Analysis 999.11 Determination of Lead, Cadmium, Copper, Iron and Zinc in Foods. 20th Edition, AOAC, Arlington, VA.

[11] Benzie, I.F. and Strain, J.J. (1996) The Ferric Reducing Ability of Plasma (FRAP) as a Measure of "Antioxidant Power": The FRAP Assay. Analytical Biochemistry, 239, 70-76. https://doi.org/10.1006/abio.1996.0292

[12] Zhu, Y., Zhao, L.L., Wang, X.F. and Li, P. (2016) Pharmacognostical and Phytochemical Studies of Viola tianschanica Maxim-An Uyghur Ethnomedicinal Plant. Journal of Pharmacy \& Pharmacognosy Research, 4, 95-106. http://jppres.com/jppres

[13] Samy, M.S. (1980) Chemical and Nutritional Studies on Roselle Seeds (Hibiscus sabdariffa L.). Zeitschrift für Ernährungswissenschaft, 19, 47-49. https://doi.org/10.1007/BF02021072

[14] Akiyoshi, S., Chiaki, N., Masaroni, M., Sadayoski, M., Yoshiharu, M. and Sadao, K. (2005) Glycosides in African Dietary Leaves, Hibiscus sabdariffa. Journal of Oleo Science, 54, 185-191.

[15] Al-Hashimi, A.G. (2012) Antioxidant and Antibacterial Activities of Hibiscus sabdariffa L. Extracts. African Journal of Food Science, 6, 506-511. http://www.academicjournals.org/AJFS

[16] Christian, K.R., Nair, M.G. and Jackson, J.C. (2006) Antioxidant and Cyclooxygenase Inhibitory Activity of Sorrel (Hibiscus sabdariffa). Journal of Food Composition and Analysis, 19, 778-783. https://doi.org/10.1016/j.jfca.2006.04.004

[17] Galicia-Flores, L.A., Salinas-Moreno, Y., Espinoza-García, B.M. and Sánchez-Feria, C. (2008) Caracterización fisicoquímica y Actividad antioxidante de Extractos de Jamaica (Hibiscus sabdariffaL.) Nacional e Importada. Revista Chapingo Serie Horticultura, 14, 121-129. https://doi.org/10.5154/r.rchsh.2007.01.005

[18] Gaitén, Y.I.G., Yaque, J.G., Lizama, R.S., Torres, Z.O., González, A.F., Jiménez, J.L.M. and Monan, M. (2018) Pharmacognostical, Phytochemical and Antioxidant Evaluations of Guettarda calyptrata A. Rich. Open Access Library Journal, 5, e4921. 